\title{
Social Protection System In Macedonia: Centralized Governance versus Decentralization
}

\author{
Natasha Bogoevska, Assistant Professor \\ University of Ss Cyril and Methodious, Faculty of Philosophy, \\ Institute of Social Work and Social Policy \\ natasa.bogoevska@fzf.ukim.edu.mk \\ Suzana Bornarova, Associate Professor \\ University of Ss Cyril and Methodious, Faculty of Philosophy, \\ Institute of Social Work and Social Policy \\ bornarova@fzf.ukim.edu.mk \\ Svetlana Trbojevik, Assistant Professor \\ University of Ss Cyril and Methodious, Faculty of Philosophy, \\ Institute of Social Work and Social Policy \\ svetlet@fzf.ukim.edu.mk
}

\section{Doi:10.5901/mjss.2013.v4n11p534}

\section{Abstract}

\begin{abstract}
In the last twenty years the Republic of Macedonia experienced significant changes of its political, economic and social system. The shift from mono-party to plural political system and transition from planned to market economy was followed by escalation of serious social tensions. The society was faced with intensification of the existing and emergence of new social problems, including those with most severe consequences, such as an increase of the unemployment rate, poverty of the households and decrease of the living standard. This imposed the need for changes of the social protection system with the goal to make it more responsive to the newly created conditions. The more intensive reforms of the social protection system started in the early 2000s and were based on the guiding principles of decentralisation, pluralisation and deinstitutionalisation. The reforming processes were at large initiated and driven by the international financial and donor organisations. Even though the goals of the transformation were well defined, the reforming processes were not thoughtfully designed, facing weaknesses in the practical implementation. The conducted researches in the area of decentralisation continuously point out to the low capacity of public and private local actors to undertake and advance their social protection roles. This paper is going to focus on the above and related problems and challenges entailed by the shift from centralised to decentralised governance in the domain of social protection in Macedonia.
\end{abstract}

Keywords: centralization, decentralization, governance, social protection, local self-government

\section{Legal and Institutional Framework of the Social Protection System}

The system of social protection in the Republic of Macedonia encompasses contributory and non contributory services and benefits. Contributory part of the system is referred to as social insurance and includes: pension and disability insurance, health insurance and unemployment insurance. The non-contributory or tax-financed part of the system referred to as social welfare encompasses: social assistance (social financial assistance (SFA); permanent financial assistance; personal care allowance; one-off financial assistance and assistance in kind), child protection, residential and non-residential care and social prevention.

The state implements the social protection of citizens in accordance with the principle of social justice. It establishes the system of social protection and enables its functioning, provides conditions and measures for social protection activities and develops self-help forms. The carriers of social protection are the Republic, local self government, the City of Skopje and the municipalities from the city of Skopje.

The social protection is determined as an activity of public interest. It is defined as a system of measures, activities and policies for prevention and overcoming the basic social risks to which the citizen is exposed throughout life, for reducing poverty and social exclusion and for strengthening citizen's capacity for self protection. The system is 
accomplished through professional work in social protection institutions, implementation of developmental programs, professional development of employee that is in accordance with beneficiary's needs and international standards, monitoring the phenomena and planning the work, record-keeping as well as monitoring and activities for research in the field. Besides the measures for social protection of the citizens, the state care for prevention of social risk is accomplished through taking measures in tax policy, employment, scholarship policy, housing, family protection, health care, education and other areas that are in accordance with law.

Central institution for policy-making, strategic planning, management, and monitoring of legality, especially through monitoring inspection over the implementation and enforcement of laws and other regulations in the field of social protection, is the Ministry of Labour and Social Policy. The Institution that studies social phenomena and promotes social activities is Public Institution for Social Affairs. The Institute for Social Affairs has its jurisdiction and monitoring over professional work in social protection institutions as well as over other legal and personal entities that perform certain activities in social protection. In order to accomplish the tasks within the social protection system a set up social protection institutions have been established (Centers for social work- CSW and social institutions for non-residential and institutional care). CSW are established as public institutions with public authorities for conducting activities in the field of social protection. They are responsible for administration of cash benefits and provision of social services.

The Government of the Republic of Macedonia adopted a National Programme for development of social protection that underlines the objectives, priorities and directions for the development of social protection of citizens, with medium and long term measures of active social policy. In accordance with this program, the municipality, the City of Skopje and its municipalities should adopt programs for the citizens need in the area of social protection. They may, by its own decision, in according to their financial capabilities determine other rights in the area of social protection, rights with greater extent than the scope of the rights determined with the Law on social protection and with better conditions for their implementation as well as other forms of social protection. The Citizens Association that is registered by the MLSP and individuals that have work permits issued by the Minister of Labour and Social Policy, may perform activities of social protection, under conditions and in a manner determined by the Law for Social Protection. Faith-based and religious groups and their associations that are registered in the Republic of Macedonia can assist people who are in need of certain types of social protection. In addition to public, the realization of the system of social protection is accomplished through establishment of public and private institutions for social protection.

The current structure of the social security system is a result of the reform processes that have taken place in the Republic of Macedonia over the past twenty years, primarily as a result of the new created conditions caused by the change in the political and economic system in the early nineties of the last century.

\section{Development path of the social protection model in Republic of Macedonia}

Republic of Macedonia functioned for 45 years as one of the constituent republics of the Yugoslav federation. It was declared an independent and sovereign state on September 8th, 1991, by referendum that led to the independence of Macedonia from the Socialist Federal Republic of Yugoslavia. The new Constitution passed on November 17, 1991, determined the Republic not only as independent and sovereign but also as a civil, democratic and social state.

The transition from a state with monopartic political system and planed economy to a one that is governed by democratic principles and the rules of the market, pluralistic in its party system with a fundamental declaration for respecting the human rights, доведе до значајни социјални тензии. During this period there was an overflow of social problems, among which the most drastic consenquences were due to the increase of unemployment, households poverty and the decrease of citizens living standard.

The system of social protection was created with the expectation to respond to the newly created conditions. This required major shifts in the values and principles upon which the social protection system in Macedonia prior to the transition was based. Within the Former Yugoslavia, Macedonia had a universal, though low quality, social protection. Social policy's aim was to achieve social balance in a society in which equality and solidarity were highly valued and the gap between the have's and have not's almost inexistent. There was high living standard and employment rate, generous housing subsidies, free and universal health care and education. The role of the state was dominant in regulating every aspect of the societal life, including social protection. Due to the lack of tradition in market economy, the private sector was weak, which entailed subsequent lack of cooperation practices, trust and even antagonism between the state and private institutions, which had to be gradually prevailed after independence. The non-governmental sector was also powerless, or under strong influence of the socialist government. Namely, the existent Women's and Pensioners' Organisations were politicized, quazi non-governmental organisations, rather than independent and influential factor in 
policy making. In addition, there was no social partnership in policy making, as the trade unions and chambers of commerce were also deeply politicized, resulting into lack of experience in organised and strong employers' organisations and trade unions' movements. A huge disadvantage at the entry into the new post-communist system was also the lack of policy-making experiences, as policy-making within Former Yugoslavia was by and large responsibility of the capital city - Belgrade institutions. Given this, Macedonia had to create the conditions for social protection development in which the state policy making capacities will be strengthened, all relevant actors will be recognised and will have a role to play in policy-making.

In the beginning, the social welfare was used as an instrument to preserve the social peace in the country, to guard against the new poor (i.e. redundant workers) and had to absorb the huge mass of people that fell into poverty due to the transition process. However, as benefits and subsidies have been scaled down by a market and cost dominated system, and as pressures from the international community to downsize social expenditures have intensified, many entitlements, services and institutions have been threatened. Some of the initial policy responses of this post-communist welfare state were: ad hock development of services and benefits; appeals to philanthropy and voluntary effort to fill gaps left by withdrawal of state services; rapid removal of subsidies on many goods and services often with limited anticipation of social consequences; limited initial privatisation of some health and social care services; encouragement of independent social initiatives in the sphere of social protection but with evident differential capacity of citizens to initiate and participate in these; deconstruction of the state social security system in favor of fully funded social insurance funds often differentiated by categories of worker; ending of privileged access by virtue of nomenklatura status of old partystate apparatus to special clinics and services; increase of local community control over local social provision but in an impoverished context where the state does not provide enough resources and the local authority has not yet established its own tax base; shift in the nature of social inequalities in use of and access to social provision from those based on bureaucratic/political privilege to those based on market relations (Deacon, et al., 1992: 170).

Consequently, as typical for most of the post-socialist countries, Macedonia too has developed a model of social protection that kept many of the characteristics typical for the Yugoslav model and amended those with others required in the process of transformation of the social protection system in the new, democratic society. It developed into a hybrid model of protection that in most part has similarities with the social democratic model typical for the Nordic countries, but is also increasingly marked with the residual elements typical for the liberal model of welfare. In addition, it shares similarities with the South European model of family care, in that it still heavily relies on the family informal care. Namely, universality and wide coverage that were preserved from the former system, currently coexist with the policies aimed at increased targeting of social benefits, activation of social welfare beneficiaries, gradual reduce of social expenditures, entry of the private sector along with the preservation of traditional non-formal family care for those in social risk. However, within this hybrid social protection model, although reforms encourage an increased involvement of private and non-governmental institutions, the social protection sector is so far still the domain of the Government (Bornarova, 2010).

\section{Reforms of the social protection system in Republic of Macedonia}

In the years after the country declared independence, the emphasis was put on the political affirmation of the state, building democratic capacity of the society and macro-economical stabilization of the economy. In that environment the state confronted a range of challenges and the necessity of reforms in every field of life. The challenge in the social sphere regarded creating a stabile normative frame and professional administrative structure through implementation of international standards in this area, as well as obeying the local specifics and tradition (Bogoevska, Jovanovska, 2010).

The reforms of the social welfare system may be grouped in three chronological phases (1) the foundation phase; (2) the institutional development phase; and 3) the reform process phase, and as such are going to be further discussed (Goverment of the Republic of Macedonia, 2010).

1. The foundation phase (1992-1996). Reform initiatives during this period of political distrust and instability had to cope with the economic social and political constraints that shaped the early nineties institutional driving forces: rising unemployment and poverty, market imperfections, incomplete regulatory structures and limited administrative capacities. Enabling full social rights coverage through legal and financial means and gradually developing anti-poverty policy instruments provided the pathway to a sound Macedonian welfare state.

The adoption of the Law on family in 1992 set up the family-legal ground where systematically were regulated issues concerning marriage and family. Social protection allowances for the vulnerable families whose overall income reaches bellow the level for decent life, were introduced with the Program for socially endangered population passed in the 1992. Heavy financial constraints due to the economic decline and the rise in 
unemployment were the serious factors to open a debate on the effectiveness and efficiency of welfare coverage. This debate shifted policy focus from traditional care policies to the poverty-line question. Thus, the establishment of a national poverty line in 1996 was the outcome of a continuous World Bank technical assistance programme which set the conditions to regulate social policies from a macro-economic point of view. This development was supplemented by the increase of capacity building in the sector of social services, where infrastructure and skills upgrading projects for the Centres for Social Work (CSWs) were implemented. Contemporary financial allowances provided urban and rural households with an ad hoc minimum income guarantee approximating $50 \%$ of the official poverty line. Level and type of benefits were amended according to the results of a World Bank Assessment Project that took place in 1997 (World Bank, 1999: 60).

In addition to the above coverage through the Family Law and the Programme for Socially Endangered Population, until 1997 the social sector in Macedonia functioned according to the Law for Social Protection passed in 1978 during the period of socialism. Changes and amendments of this law were made in 1985, 1991 and 1995, all referring to information and administrative aspects of the provision. In 1997 a new Law on Social Protection was passed which established new approached in dealing with social problems and marked the entry into the next, institutional development phase.

2. The institutional development phase (1997-2002). The Law on Social Protection passed before the Parliament in September 1997 was the cornerstone for the establishment of a modern social welfare system that took into account both the European principles on social protection and national peculiarities or needs. The Law established general and categorical minimum income schemes for persons in need without sufficient subsistence means, and brought national attitudes to welfare closer to the European minimum income guarantee machinery (MLSP, 2004: 23). The 1997 Law on Social Welfare contained a stipulation giving right to the Government to regulate the conditions for the social financial assistance (SFA) by a Governmental Decree. Although this meant interference of the executive over the legislative power, the first such Decree was still enacted in 1998.

In addition to the 1997 Law on Social Welfare, welfare measures were extended to children through the adoption of the Law on Child Protection in 2000. In the domain of protection of children, in this phase UNICEF extensively promoted and supported the deinstitutionalisation process for children with disabilities.

Apart from rights-based strategies, the period 1997-2002 was also characterised by policy responses to the Kosovo crisis (March-June 1999) that shifted the focus away from the social welfare reforms. Macedonia received more than 350.000 Kosovo refugees (more than $18 \%$ of the population), camps were set up to accommodate the refugees, while welfare institutions provided support in kind or services (MLSP, 2004: 2425). Maintaining political, security, economic and monetary stability in such circumstances entailed unprecedented challenges. The security threats as well as the hosting of half of the refugee population in homes of the citizens of Macedonia, mostly from Albanian ethnic origin, led to mounting pressures on public infrastructure and services and translated to considerable economic costs. Having weathered the Kosovo crisis in 1999, Macedonia maintained relative political and economic stability throughout 2000. However, in late February 2001, long-simmering ethnic tensions escalated and resulted in the lare-up of violence in Albanian-inhabited villages in the north of the Country close to the border with Kosovo. The conflict between ethnic Albanian armed groups and Macedonian security forces erupted in February 2001 and intensified during the summer months, leading to displacement of some $170.000,00$ persons both within the country and into neighboring territories. The six months long conflict ended up with the signing of the Framework Agreement on 13 August 2001 by four largest political parties and witnessed by representatives of the EU and USA. The cease-fire, progress on implementation of the Framework Agreement and deployment of NATO troops have encouraged some displaced people to return to their homes (UNDP, 2001: 5). ${ }^{1}$

3. The reform process phase (2002-). The most significant reforms in the area of social welfare commenced in 2004 with the changes and amendments effectuated to the existing Law on Social Protection. In this period there was a broader re-orientation towards social inclusion, wider range of services and services based on individual needs for care. It was recognised that social services should safeguard the interests of those who are not able to satisfy their needs, such as the older people, the disabled, and other categories of people in social need (Spasovska, 2008: 170). The 2004 Law was passed with no considerable critics by the opposition

1 Previously, Macedonia also offered protection to 1180 persons from Albania in 1991 and around 35.000 refugees from Bosnia in 1992 , in shelters and collective centres (MLSP, 2008b: 8). 
parties. On the contrary, it gained the support of the opposition as it was appraised as a contemporary Law that promises modernisation and improvements in social welfare in the country. It introduced the following principles that strengthened the adaptation of the Macedonian system to the European and international principles: deinstitutionalization, decentralization and welfare pluralizam.

During 2005, the reform process continued with the amendments to the Law on Social Protection and introduction of the obligation of each citizen to meet his/her own basic needs and the needs of the persons he/she is obliged to care for. The option for compensation by persons who had been receiving social assistance unjustly, was also introduced. Social inspection over the legitimacy was introduced as well, not only for the social welfare institutions, but also for the physical and legal service providers. For this purpose a Sector for Social Inspection was established as organisational unit of the MLSP (Spasovska, 2007: 176-177). The same year, there was a change in the way SFA was regulated. As previously mentioned, from 1998-2007 the conditions relative to the receipt of the SFA were regulated with a Governmental Decree. This gave discrete power to the Government to change it upon suggestions by the MLSP without any influence from the opposition parties. In 2007 the Constitutional Court abolished this stipulation in the Law on Social Welfare, thus returning back the legislative function to the Parliament. Immediately after this, subsequent changes were made in the Law on Social Welfare to prevented gaps in coverage and eventual consequences for beneficiaries due to these changes.

With the changes and amendment of the Law on Social Protection in 2007, a stipulation for prohibition of racial and ethnic discrimination was incorporated following the EU Directives.

In June 2009 a new Law on social protection was passed which attained redefinition of the social rights regarding improved realization of the social protection programs, in order to ensure better standardization of conditions and procedures in achieving social protection cash transfers rights, better targeting of the most endangered categories of social rights beneficiaries. Also, the process of deinstitutionalization and development of community based services continued with introduction of new types of social services such as independent living support and small group homes.

The future development of social protection in the Republic of Macedonia is funded on two key strategic documents adopted in 2010: National program for development of social protection 2011-2021 and the Strategy for reduction of poverty and social exclusion 2010-2020. Both documents are prepared with the implementation of wide consultative process and provide further realization of the key principles of the reform: decentralization, deinstitucionalization and pluralisation.

\section{Decentralization of social protection system}

The processes of decentralization of the competences and the reform of the local self-government have become the key priority of the political reforms in the Republic of Macedonia.

The constitutional amendments from 2001 determined that the majority of the administrative functions of the state apparatus that were concentrated at the central level will be directly given under the competence of municipalities. Therefore, the citizens through their representatives will participate in decision-making processes in the area of: health care, culture, sports, education, social and child protection, urban planning, public services, rural planning, and local economic development. After the constitutional changes, the need for a new Law on local self-government was imposed. This Law operationalised the constitutional norms and created grounds for initiating the process of decentralization. The new Law, adopted in 2002, represents a qualitative change compared to the former, with number of functions that are now the responsibility of local self-government. The idea of increasing the powers of local self-government aimed to reduce the power of the central government and to create capacities of local self-government that will be a counterweight to the central government. On the other hand, the central government is released from the load imposed by common local issues and problems that with the process of decentralization will be a daily commitment of the local selfgovernment. In other words, the purpose of the Law is to increase efficiency and to provide faster, better and cheaper services to citizens. According to this Law, Macedonian municipalities are autonomous in their work and in performance of its functions, of local and of public interest, which are in compliance to Law. These competencies are complete and exquisite and cannot be taken away from municipalities or limited, except in cases specified by law. The principle of subsidiarity is largely present in the Law for Local Self-Government through the right of the municipalities within their jurisdiction to carryout activities of public interest and local importance that are not excluded from their jurisdiction and not fall under the jurisdiction of the central government. Municipalities exercise their jurisdiction through bodies that have been directly elected by citizens or by the municipal council and the mayor (Spasov, 2009).

The adoption of the Law on Local Self-Government, The Law on Territorial Organization, the Law on Financing of 
Local Self-Government and the Law on the City of Skopje created all necessary legal prerequisites for initiating of the functional, administrative and fiscal decentralization.

Passing the package of Laws on decentralization precisely determined the responsibilities of the municipalities; it contributed in increasing of the direct participation of citizens in the public life; new method of legal and financial control of the local authorities; redefining of the financial and other relations between the central and the local government. In the list of responsibilities decentralized on the local level are also situated certain issues from the sphere of social and children protection. This issue was regulated in detail by the Law on social protection under which the state (the central government) remains responsible for the social protection of the citizens according to the principle of social justice. The state is founding the social protection system and provides its functioning, provides conditions and measures for performing social-protective activity and develops forms of self-help. The novelty is consisted in the fact that as social protection carriers are also introduced the municipality, the city of Skopje and the municipalities in the city of Skopje. The local self-government units provide social protection to different categories of persons in risk through the institutional and non-institutional forms of social protection, housing and raising awareness of the population for the necessity of ensuring social protection. They can, with their own decision and in accordance with material possibilities, determine other rights in the field of social protection, rights in wider range than the rights stipulated by the central government and more favorable conditions for their realization, as well as other forms of social protection.

\subsection{Implementation of the principle of decentralization}

Despite the legislative and political declaration, the local governments still remain ill-prepared for their new roles, social functions of municipalities are not developed and local social services networks as a result are very scarce.

The studies show that there has not been a more significant improvement in the development of social protection activities at local level. The activities of local self-government in the area of social protection mainly are connected to administration of cash benefits and are based on the discretion right in decision making by the major of the municipality. Basically, the budget for social protection has been used for one term material assistance to persons and families in need of hospitalization or in cases of harm reduction from elementary damages or alike. The municipality is not a direct distributor of social services for the vulnerable groups of citizens, but in some cases supports pre-established social services through covering the expenses for food, transportation, utilities, etc. Most of the municipalities within their budgets provide means for social protection that are in the range between $0.3 \%$ and $1 \%$ from the basic budget (not counting the supplements from the central budget).

The designation on the amount of the administered social protection from the budget of the municipality is on voluntary bases and is not based on the identified needs. Smaller municipalities have limited budgetary planning and expenses for social protection, in part of them that is due to the freezing of their accounts with the court decision.

The municipalities do not posses satisfactory administrative capacities for distribution of social services for their citizens. They do not have the capacity for identification of the specific needs for social protection on their territory, knowledge for strategic planning in the field of social protection. In accordance to the Law on social protection and the National program for the development of social protection 2011-2021, the municipalities should prepare annual programs for social protection needs of citizens and they should submit them for an opinion to the Ministry of Labour and Social Policy. The programs are not prepared in accordance to standard methodological criteria that should be regarded in the process of development of such programs. Mainly, they have not been based on inclusive and profound analysis and research of the conditions of the vulnerable groups in the municipality nor through a wider consultative process between the local actors. Consequently, the programs are conceptually and contextually poor, formal, not comprehensive and do not reflect the real needs of its citizens. In all of the municipalities the lack of financial means is pointed out as a basic obstacle for implementation of these programs.

In the current constellation of relationship, the Centres for social work remain the basic carriers of social protection and social services of the municipalities. Yet, due to the fact that they are centrally organized and are subjected to social inspection and monitoring over their work and implementation of acts, their acting is based on implementation of centrally created policies and their implementation on local level that are not always in compliances with the specifics of the vulnerable groups from the local communities. Also, the Centres for social work are financed by the State budget and their planning in the area of budgeting is in the framework of the available means provided on central level and within the central policies of the MLSP.

Other actors (NGOs, private sector, and religious organizations) are not sufficiently involved in the delivery of social services at the local level primarily due to: lack of political will to develop pluralistic social protection, lack of 
knowledge on the advantages from applying multi-sector cooperation, undeveloped NGO sector, lack of a sense of social responsibility and lack of sustainability of implemented projects (Bornarova, Bogoevska, 2012).

\section{Conclusion}

The system of social protection is crucial of crucial meaning for provision of social security and the welfare of citizens in every social state. After its independence, the Republic of Macedonia inherited highly centralized social security system with the dominant role of the state as provider of protection and insignificant participation of non-governmental, private and religious sectors in social protection activities. Within this system, the social protection was at large accomplished through cash transfers and benefits to citizens in social risk. Social services as nonfinancial measures aimed at improving the social functioning of individuals and groups at social risk, were underdeveloped and reduced primarily to institutional forms of care.

Since its independence in 1991, the Republic of Macedonia has been undertaking activities to create a modern, stable and functional system of social protection that will respond to the newly emerging needs of its beneficiaries. The system of social protection inherited from the former Yugoslavia had to adapt to the new social context and the new social problems imposed by the transition period. Namely, over this period there was an increase in unemployment, a drop in the standard of living, a reduction in the gross domestic product and an increase in the social vulnerability of many citizens that were directly affected by the transformation of the socio-economic system in the process of privatization of state-owned capital and other social events. This situation entailed a need for implementation of a series of reform processes in the area of social protection, as well as adoption of new principles and methods of work.

In the Republic of Macedonia, the past two decades and more intensively after 2000, continuous changes have been made with the attempt to reform the system of social protection, especially in the area of social services. The key changes are based on the principle of pluralism that was implemented in the direction of reducing the state's role as a direct provider of services and strengthening of the state role in providing social services through involvement of other sectors (private, NGO, religious) as partners of the state. Also, great attention is paid to developing alternative forms of protection for reduction the former dominant dependence from institutional care and to the process of deinstitutionalization. One of the biggest challenges in the reform process is the decentralization of social services which includes building local networks of social services tailored to the specific needs of the citizens in all municipalities.

The implementation of the decentralization process inevitably requires municipalities to take the lead role in developing a local system of social services through multi-sector collaboration. However, due to the lack of experiences and practices, the undeveloped social-protection functions of municipalities, lack of capacities, incomplete fiscal decentralization as well as insufficient inter-institutional cooperation at the local level in the area of social services, points out on a slow implementation of the decentralization process. Only public homes for older people (3 out of 4 ) and kindergartens (44) have been decentralized to municipalities. The 2004 changes and amendments of the Law on Social Welfare also encouraged municipalities to prepare Development Programmes and to initiate decentralization of the existing day-care centers currently operating as units of the local CSWs. Municipalities have not yet taken over the daycare centers due to several reasons: first, the law does not require that municipalities "must" but it is provided that they "may" take over when they will be ready for such a venture. Secondly, due to the lack of financial funds the local self-government units and due to the fact that the day-care centers (DC) are currently organizational units of the Centers for Social Work (CSW), and not independent legal entities that can be transferred to municipalities (although this constraint can be resolved with their re-registration).

Belated process of financial decentralization, which has been implemented from July 2007 , is another obstacle to effective decentralization of social protection. It is expected that existing day-care centers will be decentralize and their financial operations will be transformed in 10 municipalities that have financial capacity to do so by the end of fiscal decentralization in Macedonia. Within the current decentralization, decentralized are only kindergartens, nursing homes and the educational institutions (Dimitrievska 2011).

It can be concluded that even though the decentralization is de jure proclaimed as a guiding principle in the system of social protection, de facto, the Republic of Macedonia in the area of social protection remains centralized welfare state in which a key role plays the Ministry of Labour and Social Policy.

\section{References}

Bogoevska,N., Jovanovska, B. (2010). Reform of the Social Protection System in the Republic of Macedonia, In: Georgeta Rata (ed.) Social Sciences and Humanities: Between Theory and Practice, London: Cambridge Scholar Publishing 
Bornarova S., (2010). Development of the Social Protection System in Post-Communist Macedonia: Social Policy-Making and Political Processes. In: Stambolieva M., (ed.) Welfare States in Transition: 20 years after the Yugoslav welfare model, Sofia: Friedrich Ebert Foundation Office Bulgaria

Bornarova, S., Bogoevska, N., (2012). Analysis of the Local Capacities and Needs for Development of Social Services for Vulnerable Groups (for four municipalities: Gostivar, Resen, Kocani and Petrovac), Skopje: UNDP-Skopje

Deacon, B., et al., (1992). The New Eastern Europe: Social Policy Past, Present and Future. London: Sage

Dimitrievska V., (2011). Mehanizmi za obezbeduvawe na socijalni uslugi vo Makedonija, Skopje: Kancelarijata na GIZ vo Skopje

Government of the Republic of Macedonia (2010), National program for development of social protection 2011-2021, Skopje

Government of the Republic of Macedonia (2010), Strategy for poverty reduction and social exclusion, Skopje

Ministry of Labour and Social Policy (2004). The Social Welfare System in FYR Macedonia. European Agency for Reconstruction.

Spasov A., (2009). Decentralizacijata vo Makedonija, Regionalen razvoj i lokalen ekonomski razvoj-sostojbi i perspektivi, Skopje: Fridrih Ebert Fondacija, Kancelarija Skopje

Spasovska S., (2007). Social Protection Reform in Macedonia: Current State, Reform Processes and Challenges. In Bornarova S., (ed). Contemporary Developments in Social Protection and Social Work - Professionalisation, Deinstitutionalisation and Reforms. Skopje: Faculty of Philosophy-Skopje.

UNDP (2001). National Human Development Report 2001. Social Exclusion and Human Insecurity in FYRM.

World Bank (1999). Focusing on the Poor-Main Report.

Law on Social Protection (Official Gazette of the Republic of Macedonia No 36/2011, 51/2011, 166/2012, 15/2013)

Law on Child Protection (Official Gazette of the Republic of Macedonia No 23/2013)

Law on Family (Official Gazette of the Republic of Macedonia No 80/92, 9/96, 38/2004, 33/2006, 84/2008, 67/2010, 156/2010, 39/2012, 44/2012)

Law on Local-Self Government (Official Gazette of the Republic of Macedonia No 5/2002)

Law on Territorial Organization in the Republic of Macedonia (Official Gazette of the Republic of Macedonia No 55/2004, 12/2005, 98/2008 и 106/2008 )

Law on Financing of Local Self-Government (Official Gazette of the Republic of Macedonia No 61/2004)

Law on the City of Skopje (Official Gazette of the Republic of Macedonia No 55/2004, 158/2011) 